\title{
GENERAL ANASTESI FACE MASK (GA FM) PADA PASIEN COMBUTIO GRADE II A
}

\author{
I Dewa Gede Oka Darsana \\ Fakultas Kedokteran Universitas Islam Al-Azhar \\ Rumah Sakit Umum Daerah Bangli
}

\begin{abstract}
ABSTRAK
Teknik general anestesi inhalasi yang dilakukan dengan jalan memberikan kombinasi obat anestesi inhalasi yang berupa gas dan atau cairan yang mudah menguap melalui alat atau mesin anestesi langsung ke udara inspirasi. Pada pasien combutio yang dilakukan tindakan debridement yang singkat $(0,5 \mathrm{jam}-1 \mathrm{jam})$ tanpa membuka rongga perut, keadaan umum pasien cukup baik (status fisik ASA I atau ASA II) dengan jenis operasi meliputi operasi kecil dan waktu pasien akan kembali sadar penuh dalam waktu 15 menit dan tidak sadar yang berlangsung diatas 15 menit dianggap prolonged.

Tujuan dari laporan kasus ini adalah mendiskusikan penatalaksanaan anastesi dengan menggunakan Face Mask (Sungkup Muka). Face Mask dapat membantu mengubah kondisi pasien yang tidak bisa diventilasi menjadi bisa diventilasi.

Pasien seorang anak laki-laki usia 3 tahun datang sadar ke RSU Bangli oleh orangtua pasien dengan keluhan nyeri pada luka bakar sejak 4 hari yang lalu. Pasien dibawa ke rumah sakit pada tanggal 26 juli 2019. Pasien memilikiDiagnosis pre operatif Combutio grade II A, dengan status operatif ASA I.
\end{abstract}

Kata Kunci : General Anastesi, Face Mask, Combutio.

\section{PENDAHULUAN}

Nestesiologi adalah cabang ilmu
kedokteran yang mendasari berbagai
tindakan meliputi pemberian anestesi,
penjagaan keselamatan penderita yang
mengalami pembedahan, pemberian bantuan
hidup dasar, pengobatan intensif pasien
gawat, terapi inhalasi dan penanggulangan
nyeri. (dorland, 2006).

Teknik general anestesi inhalasi yang dilakukan dengan jalan memberikan kombinasi obat anestesi inhalasi yang berupa gas dan atau cairan yang mudah menguap melalui alat atau mesin anestesi langsung ke udara inspirasi. Pada pasien combutio yang dilakukan tindakan debridement yang singkat $(0,5$ jam -1 jam $)$ tanpa membuka rongga perut, keadaan umum pasien cukup baik (status fisik ASA I atau ASA II) dengan jenis operasi meliputi operasi kecil dan waktu pasien akan kembali sadar penuh dalam waktu 15 menit dan tidak sadar yang berlangsung diatas 15 menit dianggap prolonged. (Rosari, Bella. 2016).

Pemilihan jenis anestesi untuk debridement ditentukan berdasarkan usia pasien, kondisi kesehatan dan keadaan umum, sarana prasarana serta keterampilan dokter bedah, dokter anestesi dan perawat anestesi. Di Indonesia, debridement dilakukan di bawah anestesi umum. Mengingat debridement merupakan tindakan bedah yang dilakukan dengan anestesi umum, komplikasi yang 
ditimbulkannya merupakan gabungan komplikasi tindakan bedah dan anestesi. (de Jong. 2012).

Tujuan dari laporan kasus ini adalah mendiskusikan penatalaksanaan anastesi dengan menggunakan Face Mask (Sungkup Muka). Face Mask dapat membantu mengubah kondisi pasien yang tidak bisa diventilasi menjadi bisa diventilasi.

\section{INVESTIGASI}

\section{Anamesis}

Pasien seorang anak laki-laki usia 3 tahun datang sadar ke RSU Bangli oleh orangtua pasien dengan keluhan nyeri pada luka bakar sejak 4 hari yang lalu. Pasien dibawa ke rumah sakit pada tanggal 26 juli 2019. Menurut ibu pasien awal dirasakan setelah kedua telapak tangan terkena api saat pasien dan ayah pasien membakar sampah disekitar rumah pasien. Nyeri dirasakan terus menerus, pada telapak tangan tampak terbakar sehingga menyebabkan pasien tidak bisa beraktivitas dan sulit untuk tidur. Keluhan mual, muntah disangkal pasien. Pasien tidak pernah mengalami keluhan seperti ini sebelumnya. Riwayat pengobatan sebelumnya disangkal pasien, pasien dibawah ke IGD RSU 2 hari yang lalu dan mendapatkan penanganan. Riwayat demam $(-)$, BAB (+) dan BAK (+) lancar.

\section{Pemeriksaan Fisik}

Keadaan Umum : Baik
Berat Badan

$: 15 \mathrm{~kg}$

Nadi

: $82 \mathrm{x} /$ menit

Respirasi

: 20x/menit

Suhu

$: 36.0^{\circ} \mathrm{C}$

NRS : 4

B1 (Brain) ： E4 V5 M6

○ Kepala : Normocephal

○ Mata : Konjungtiva tidak anemis, sclera tidak ikterik, kedua pupil isokor.

\section{B2 (Breath) :}

○ Inspeksi : Bentuk simetris, gerak pernafasan statis dan dinamis.

- Simetris, tetraksi sela iga (-).

○ Palpasi : Fremitus vocal dan taktil simetris kanan dan kiri, tidak .

- Teraba massa, krepitasi (-).

○ Perkusi : Sonor diseluruh lapang paru.

- Auskultasi : Suara nafas vesikuler, ronkhi -/-, wheezing -/-.

\section{B3 (Blood) :}

○ Inspeksi : Iktus kordis tidak terlihat

- Palpasi : Pulsasi iktus kordis teraba sela iga kelima linea

○ Midklavikuka sinistra

○ Perkusi : Batas jantung kiri sela iga $\mathrm{V}$ line midklavikula sinistra,

- Batas jantung kanan sela iga V linea parasternal dextra,

- Batas pinggang jantung sela iga II linea parastelnal Sinistra.

○ Auskultas : Bunyi jantung I - II reguler, tidak ditemukan gallop maupun 
murmur.

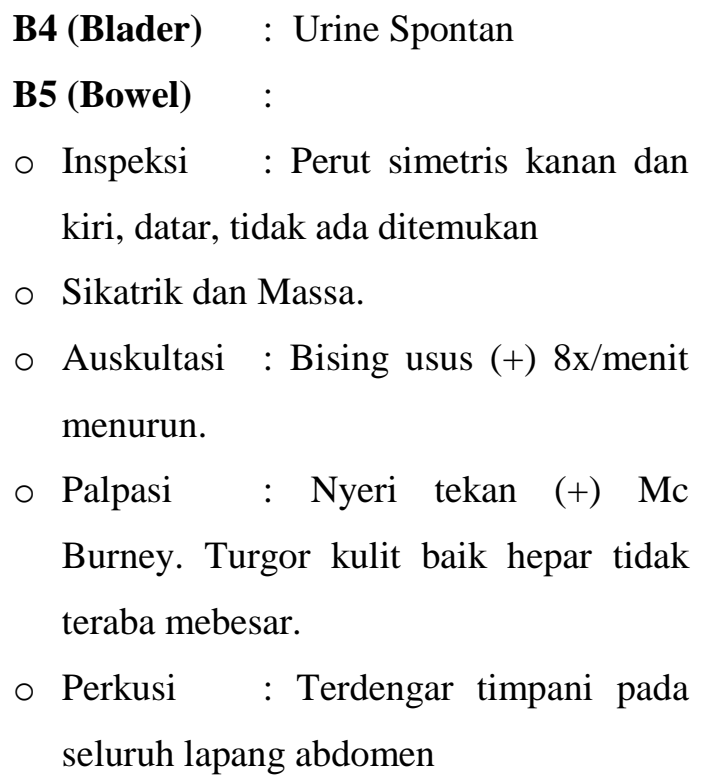

B6 (Bone) : Akral hangat, fraktur (-).

PEMERIKSAAN LABORATORIUM

Darah Lengkap (Tanggal 29 Juli 2019)

- WBC :9,4

- $\mathrm{RBC}: 4,40$

- HGB : 11,6

- HCT : 34,9

- PLT: 348

- BT : 3'00"

- CT : 8'30"

Berdasarkan anamnesis, pemeriksaan

fisik dan pemeriksaan penunjang, maka didapatkan :

- Diagnosis pre operatif : Combutio grade II A.

- Status operatif : Status Fisik ASA I.

- Jenis operasi : : Debridement.
- Jenis anestesi : General Anastesi

Face Mask.

\section{TATALAKSANA}

Saat pasien berada di ruangan preoperasi, pasien diberikan obat-obatan premedikasi, yaitu :

Sedative : Midazolam 0,05-0,1 $\mathrm{mg} / \mathrm{KgBB} \quad \rightarrow 1 \mathrm{mg}$ (IV)

Analgetik : Antrain 8-16 mg/KgBB $\rightarrow 150 \mathrm{mg}$ (IV)

Antiemetik : Ondancentron 0,05-0,1 $\mathrm{mg} / \mathrm{KgBB} \quad \rightarrow 1 \mathrm{mg}$ (IV)

Ranitidine $1-2 \mathrm{mg} / \mathrm{KgBB} \rightarrow 15 \mathrm{mg}$ (IV)

- Pasien dibaringkan di meja operasi

- Pemberian obat-obatan induksi : Fentanyl 1-2 $\mu \mathrm{g} / \mathrm{KgBB} \rightarrow 15 \mu \mathrm{g}$ (IV) Propofol 2-2,5mg/KgBB $\rightarrow 30 \mathrm{mg}$ (IV)

- Oksigenasi dengan O2 6-10 liter/menit.

- Memompa nafas pasien sesuai dengan frekuensi nafas normal ( \pm 14-18 kali per menit).

- Maintenance dengan sevoflurance $2 \%$, N20 70\%, dan O2 30\%.

- Setelah operasi selesai, melakukan pembersihan jalan nafas dari sekret dengan menggunakan suction.

- Ekstubasi ET setelah os bernafas spontan Pemantauan Selama Anestesi 
Melakukan monitoring secara kontinue tentang keadaan pasien yaitu reaksi pasien terhadap pemberian obat anestesi khususnya terhadap fungsi pernapasan dan jantung.

Kardiovaskular : Nadi dan tekanan darah setiap 5 menit.

Respirasi : Inspeksi pernapasan spontan \& saturasi oksigen.

Cairan : Monitoring input cairan.

\section{Terapi Cairan}

1. Cairan pengganti puasa : Pasien puasa sejak pukul 24.00 WITA

Maintenance (M) $\quad-10 \mathrm{~kg} \mathrm{I}$ : $4 \mathrm{cc} / \mathrm{kgBB} / \mathrm{jam}$

- $10 \mathrm{~kg}$ II $\quad: 2 \mathrm{cc} / \mathrm{kgBB} / \mathrm{jam}$ - $10 \mathrm{~kg}$ III

$: 1 \mathrm{cc} / \mathrm{kgBB} / \mathrm{jam}$

$=10 \mathrm{~kg} \mathrm{I}$

: $4 \mathrm{cc} / \mathrm{kgBB} / \mathrm{jam} \times 10 \mathrm{~kg}=40 \mathrm{cc}$ $=10 \mathrm{~kg} \mathrm{II}$

$: 2 \mathrm{cc} / \mathrm{kgBB} / \mathrm{jam} \times 5 \mathrm{~kg}=10 \mathrm{cc}$ Total $=50 \mathrm{cc} / \mathrm{jam}=17 \mathrm{tpm}$

\section{Instruksi Post Operasi}

- Bila kesakitan : Paracetamol 3 x 150 mg

- Infus : RL 12 tpm

- Minum/Makan : Belum boleh

\section{Pembahasan dan Diskusi}

Dari hasil kunjungan pra anestesi baik dari anamnesis, pemeriksaan fisik akan dibahas masalah yang timbul, baik dari segi medis, bedah maupun anestesi. Pasien Laki- laki 3 tahun datang ke ruang operasi untuk menjalani operasi debridement pada tanggal 30 Juli 2019 dengan diagnosis Combutio grade II A.

Kerusakan hampir seluruh bagian dermis. Apendises kulit seperti folikel rambut, kelenjar keringat, kelenjar sebasea sebagian masih utuh. Penyembuhan terjadi lebih lama, tergantung apendises kulit yang tersisa. Biasanya penyembuhan terjadi dalam waktu lebih dari satu bulan (Moenajat, 2006)

Luka bakar merupakan suatu keadaan yang sangat jauh berbeda dengan penyakit atau kelainan yang ada. Kompleksitas permasalahan yang ada pada setiap fase menyebabkan kesulitan dalam menyusun suatu bentuk standar pelayanan baku, sehingga memerlukan beberapa alternatif. Sebagai jalan keluar untuk mengatasi permasalahan standar pelayanan ini, maka penyusunan standar kembali mengacu pada evidence-based medicine yang terdiri dari beberapa kategori; menghasilkan beberapa kelas rekomendasi. (Cushieri A, 2008.)

Persiapan operasi dilakukan pada tanggal 29 Juli 2019. Dari anamnesis terdapat keluhan nyeri pada luka bakar sejak 4 hari yang lalu. Menurut ibu pasien awal dirasakan setelah kedua telapak tangan terkena api saat pasien dan ayah pasien membakar sampah disekitar rumah pasien. Nyeri dirasakan terus menerus, pada telapak 
tangan terasa seperti terbakar sehingga menyebabkan pasien tidak bisa beraktivitas dan sulit untuk tidur. Keluhan mual, muntah disangkal pasien. Pasien tidak pernah mengalami keluhan seperti ini sebelumnya. Riwayat pengobatan sebelumnya disangkal pasien, pasien dibawah ke IGD RSU 2 hari yang lalu dan mendapatkan penanganan. Riwayat demam (-), BAB (+) dan BAK (+) lancar. Pemeriksaan fisik dari tanda vital didapatkan; tekanan darah tidak dilakukan, nadi $82 \mathrm{x} /$ menit; respirasi $22 \mathrm{x} /$ menit; suhu $36,0^{\circ} \mathrm{C}$, VAS 4. Dari pemeriksaan laboratorium yang dilakukan tanggal $29 \mathrm{Juli}$ 2019 dalam batas normal. Dari hasil anamnesis, pemeriksaan fisik dan pemeriksaan penunjang disimpulkan bahwa pasien masuk dalam ASA I yaitu penyakit bedah tanpa disertai penyakit sistemik.

Sebelum dilakukan operasi pasien dipuasakan selama 8 jam. Tujuan puasa untuk mencegah terjadinya aspirasi isi lambung karena regurgitasi. Aspirasi isi lambung, penyebab, akibat dan gejalanya dapat dibedakan oleh 3 bahan aspirat yaitu berupa asam, partikel (sisa makanan) dan bakteri. Secara umum aspirasi dapat dicegah dengan mencegah isi lambung agar tidak masuk ke faring, aspirasi yang di faring dijaga tidak masuk trakhea dan paru.

Selain bahan aspirat, volume isi lambung menentukan keparahan akibat aspirasi sehingga jumlah yang cairan masuk paru diupayakan menjadi lebih sedikit. Timbulnya reaksi akibat aspirasi asam dapat terlihat segera setelah kejadian atau gejala yang timbulnya lambat. Aspirasi asam lambung terjadi 2 fase yaitu trauma pada jaringan dan reaksi keradangan. Dalam waktu 5 detik, asam akan bereaksi dengan mukosa trakhea dan alveoli, dan dalam waktu 15 detik telah terjadi netralisasi. Enam jam kemudian akan kehilangan lapisan sel superfisial yang bersilia dan yang tidak bersilia. Regenerasi terjadi dalam waktu 3 hari, dan dalam waktu 7 hari terjadi regenerasi yang sempurna pada sel yang mengalami kerusakan. Sel alveolar tipe II sangat peka terhadap asam hidroklorid dan mengalami kerusakan dalam waktu 4 jam setelah terjadinya aspirasi. Peningkatan lisophophosphatidyle choline yang cepat dalam 4 jam setelah aspirasi asam mengakibatkan peningkatan permiabilitas alveolar dan cairan paru (lung water). Peningkatan cairan paru mengakibatkan menurunkan compliance paru, menurunkan kemampuan perfusi-ventilasi paru. Pada fase kedua, ditandai dengan pelepasan sitokin sitokin inflamasi yag terangsang dengan adanya zat asam seperti TNF $\alpha$ dan interleukin-8. Hal ini akan merangsang ekspresi sel adhesion molecule L-selectin dan beta- 2 integrins pada neutrofil, and intercellular adhesion molecules (ICAM) pada endothel paru yang selanjutnya 
merangsang reaksi peradangan (neutrophilic inflammatory response). (Ting, H. Paul. 2002).

Akibatnya memicu reaksi peradangan yang menyeluruh yang memungkinan terjadinya kegagalan kardiopulmoner. Aspirasi isi lambung secara bersamaan menyebabkan terjadi fokus peradangan dan reaksi tubuh terhadap benda asing dengan kerusakan jaringan secara menyeluruh akibat asam. Partikel dan asam lambung bekerja sama secara sinergis menyebabkan kebocoran kapiler alveolar. Aspirasi partikel besar dari isi lambung, akan menimbulkan gejala obstruksi jalan napas, dan dalam waktu pendek dapat terjadi kematian pasien, oleh karena itu partikel tersebut harus segera dikeluarkan, dan dilakukan oksigenasi dan ventilasi untuk menghindari hipoksia, dan segera dilakukan intubasi untuk mencegah aspirasi selanjutnya. Isi lambung tidak steril sehingga aspirasi yang terjadi dapat disertai bakteri. 60-100\% terdiri dari kuman anaerob. Gabungan kuman aerob dan anaerob sering dijumpai pada aspirasi pneumoni yang terjadi di rumah sakit. Pseudomonas aeroginosa, Klebsiella dan Escheresia colli merupakan kuman gram negatif yang banyak dijumpai sebagai penyebab pneumonia nosokomial. Staphylococcus aureus merupakan kuman gram positif yang patogen. (Ting, $\mathrm{H}$ Paul. 2002).
Kuman gram negatif yang dijumpai pada pemakaian ventilator, $34 \%$ berasal dari aspirasi isi lambung dan sekret orofaring, dan diduga merupakan penyebab kematian pneumonia pasca bedah. Penggantian puasa juga harus dihitung dalam terapi. (Moore KL. 2002).

Pemilihan teknik anestesi pada pasien adalah anastesi umum dengan pemasangan sungkup muka. Alasan pemilihan teknik anestesi ini berdasarkan indikasi sebagai berikut :

- Untuk tindakan yang singkat $(0,5$ jam - 1 jam) tanpa membuka rongga perut.

- Keadaan umum pasien cukup baik (status fisik ASA I atau ASA II).

- Lambung harus kosong.

Pasien masuk ke ruang operasi pada pukul 10.00 WITA dilakukan pemasangan monitoring, nadi, saturasi, dengan hasil nadi 93x/menit, dan $\mathrm{SpO}_{2}$ 100\%. Pada pasien ini, urutan tindakan anastesi dimulai dari preoperatif, intraoperatif, dan postoperatif.

Pada pasien diberikan antibiotik untuk pencegahan infeksi yaitu cefotaxime 1 gr. Cefotaxime merupakan antibiotik spektrum luas yang dapat digunakan terhadap berbagai kuman gram-positif maupun negatif. Obat ini merupakan golongan sefalosporin generasi ketiga. (goodmann, 1985).

Pasien diberikan obat - obat premedikasi bertujuan untuk menimbulkan 
rasa nyaman bagi pasien, mengurangi sekresi kelenjar dan menekan refleks vagus, memperlancar induksi, mengurangi dosis obat anestesia, mengurangi rasa sakit dan gelisah paska bedah, menimbulkan amnesia retrograde pada pasien ini, obat-obatan yang dipilih adalah sebagai berikut :

\section{a. Premedikasi}
- Sedatif : Midazolam injeksi
$5 \mathrm{mg}$ (IV) Konsentrasi $5 \mathrm{mg} / \mathrm{ml}$ dalam 1 ampul $1 \mathrm{ml}$.

Diberikan secara intravena. Berdasarkan teori premedikasi pasien diberikan obat golongan sedatif yaitu midazolam dengan dosis $0,05-0,1 \mathrm{mg} / \mathrm{KgBB}$ dengan tujuan untuk mendapatkan efek sedatif dari obat tersebut sehingga pasien akan merasa nyaman dan tidak takut saat berada di ruang operasi, dimana juga untuk mencapai tujuan dari premedikasi tersebut. Pemberian sedatif ini perlu diberikan pada pasien yang akan dilakukan tindakan anastesi mengalami kecemasan atau ketakutan akan mempengaruhi tekanan darah, nadi, dan proses anastesi yang akan dilakukan. Pada pasien ini diberikan midazolam $1 \mathrm{mg}$ IV untuk medapatkan efek sedasi yang terkandung dalam midazolam sehingga menmbuat pasien tertidur dan tidak merasakan cemas akibat tindakan operasi. (Dachlan M, R. 2009).

Analgesik: Paracetamol flash $1000 \mathrm{mg}$
(IV) Konsentrasi 10 mg/ml dalam dalam 1 flash $100 \mathrm{ml}$.

Diberikan secara intravena. Paracetamol tersedia sebagai obat tunggal, berbentuk tablet $500 \mathrm{mg}$ atau sirup yang mengandung $120 \mathrm{mg} / 5 \mathrm{ml}$. Selain itu Parasetamol terdapat sebagai sediaan kombinasi tetap, dalam bentuk tablet maupun flash. Dosis Parasetamol untuk dewasa 300mg-1g per kali, dengan maksimum $4 \mathrm{~g}$ per hari, untuk anak 6-12 tahun: 150-300 mg/kali, dengan maksimum 1,2g/hari. Untuk anak 1-6 tahun: $60 \mathrm{mg} / \mathrm{kali}$, pada keduanya diberikan maksimum 6 kali sehari. (Goodman and Gilman's. 1985).

Parasetamol cepat diabsorbsi dari saluran pencernaan, dengan kadar serum puncak dicapai dalam 30-60 menit. Waktu paruh kira-kira 2 jam. Metabolisme di hati, sekitar $3 \%$ diekskresi dalam bentuk tidak berubah melalui urin dan 80-90 \% dikonjugasi dengan asam glukoronik atau asam sulfurik kemudian diekskresi melalui urin dalam satu hari pertama; sebagian dihidroksilasi menjadi $\mathrm{N}$ asetil benzokuinon yang sangat reaktif dan berpotensi menjadi metabolit berbahaya. Pada dosis normal bereaksi dengan gugus sulfhidril dari glutation menjadi substansi nontoksik. Pada dosis besar akan berikatan dengan sulfhidril dari protein hati. ${ }^{7}$

- Antiemetik: Ondancentron injeksi 4 mg 
(IV) Konsentrasi $4 \mathrm{mg} / 2 \mathrm{ml}$ dalam 1 Ampul $2 \mathrm{ml}$, dosis 0,05-01 mg/kgBB

Ondansentron, sebagai anti emetik, suatu antagonis selektif $5-\mathrm{HT}_{3}$, menghambat serotonin dan bekerja berdasarkan mekanisme sentral dan perifer. Mekanisme sentral dengan mempertinggi ambang rangsang muntah di chemoreceptor trigger zone. Mekanisme perifer dengan menurunkan kepekaan saraf vagus terminalis di visceral yang menghantar impuls eferen dari saluran cerna ke pusat muntah.Onset 30 menit, dengan durasi 3 jam. Pada pasien ini diberikan ondancentron $1 \mathrm{mg}$ (IV) untuk mendapatkan efek emetik sehingga pasien tidak merasakan mual ataupun muntah saat dilakukan induksi operatif ataupun pasca operatif.

(Goodman and Gilman's. 1985).

Ranitidine injeksi $50 \quad \mathrm{mg} \quad$ (IV)

Konsentrasi $50 \mathrm{mg} / 2 \mathrm{ml}$ dalam 1 ampul 2

$\mathrm{ml}$, dosis $1-2 \mathrm{mg} / \mathrm{kgBB}$.

Efek pada Gastrointestinal, ranitidine bekerja dengan menghambat secara kompetitif reseptor histamin $\mathrm{H} 2$ menghambat kerja histamin secara kompetitif pada reseptor $\mathrm{H} 2$ dan mengurangi sekresi asam lambung.Dosis intravena intermiten atau intramuskular pada dewasa adalah 50 mg setiap 6-8 jam.Jika perlu dosis dapat dapat ditingkatkan dengan meningkatkan frekuensi pemberian, namun tidak boleh melebihi 400 mg perhari. Pada pasien ini diberikan ranitidine injeksi $15 \mathrm{mg}$ (IV) untuk mendapatkan mencegah agar tidak terjadinya aspirasi ke paru-paru. (Goodman and Gilman's. 1985).

\section{b. Induksi}

- Fentanyl injeksi 100 mcg (IV) Konsentrasi 0,05 mg/ml dalam 1 ampul 2 $\mathrm{ml}$, dosis $12 \mathrm{mcg} / \mathrm{kgBB}$.

Fentanyl, merupakan golongan obat opioid analgetik poten yang terutama bekerja sentral pada sistem saraf pusat, sehingga mengakibatkan meningkatnya ambang batas nyeri, mengurangi persepsi nyeri menghambat serabut saraf nyeri ascending, menyebabkan depresi nafas dan sedasi.Pada dosis lazim kesadaran pasien menurun dan khasiat analgetiknya yang kuat. Onset 30-120 detik dengan durasi 3060 menit. Dosis 1-2 mcg/kgBB IV. Tujuan dari pemberian fentanyl adalah untuk meningkatkan kualitas analgesia intraoperative dan dapat menghasilkan onset 1 sampai 2 menit dan dari analgesia berdurasi 30 menit sampai 1 jam. Pada pasien ini diberikan fentanyl injeksi $15 \mu \mathrm{g}$ (IV).

- Propofol injeksi 30 mg (IV) Konsentrasi $10 \mathrm{mg} / \mathrm{ml}$ dalam 1 ampul berisi $20 \mathrm{ml}$, dosis pemberian 2-2,5mg/kg/BB.

Propofol dianggap memiliki efek sedative hipnotik melalui interaksinya dengan reseptor GABA dengan cara meningkatkan GABA. Pada pemberian 
dosis induksi (2 $\mathrm{mg} / \mathrm{kgBB})$, pemulihan kesadaran berlangsung cepat, pasien akan bangun 4-5 menit tanpa disertai efek samping. Khasiat farmakologinya adalah hipnotik murni, tidak mempunyai efek analgetik maupun relaksasi otot. Walaupun terjadi penurunan tonus otot rangka, hal ini disebabkan oleh efek sentralnya Induksi anestesia 2,0-2,5 mg/kgBB. Pada bayi dan lansia dosis disesuaikan.Pasien tua memerlukan dosis induksi lebih rendah $25 \%$ - 50\% dari dosis lazim. Pada pasien ini diberikan propopol injeksi $30 \mathrm{mg}$ (IV).

Induksi fentanyl $15 \mathrm{mcg}$, propofol 30

mg intravena pada pasien di atas bertujuan untuk mendapatkan efek berupa hipnotik dan analgesia, sedangkan pada pasien ini tidak diberikan obat pelumpuh otot karena tidak ada indikasi pemberian.

Selama operasi berlangsung dilakukan pemantauan tanda vital berupa tekanan darah, nadi , dan saturasi oksigen setiap 5 menit secara efisien dan terus menerus, dan pemberian cairan intravena berupa RL. Cairan yang diberikan adalah RL (Ringer Laktat) karena merupakan kristaloid dengan komposisinya yang lengkap $\left(\mathrm{Na}^{+}\right.$, $\mathrm{K}^{+}, \mathrm{Cl}^{-}, \mathrm{Ca}^{++}$, dan laktat) yang mengandung elektrolit untuk menggantikan kehilangan cairan selama operasi, juga untuk mencegah efek hipotensi akibat pemberian obat-obatan intravena dan gas inhalasi yang mempunyai efek vasodilatasi. (Murray MJ. 2006).
Pada pasien ini diberikan maintanance $\mathrm{O} 2: \mathrm{N} 2 \mathrm{O}:$ sevofluran $=40: 60$ : 2 vol \% secara inhalasi dalam kasus ini yaitu face mask dengan tujuannya yaitu untuk memperpanjang durasi obat induksi.

Selama operasi keadaan pasien stabil. Setelah tindakan oprasi selesai, gas O2 dihentikan dan observasi dilanjutkan pada pasien di recovery room, dimana dilakukan pemantauan tanda vital meliputi tekanan darah, nadi, respirasi dan saturasi oksigen dan menghitung aldrete score. (Ting, $\mathrm{H}$. Paul, 2002).

Masalah yang timbul pada Pasien dan Penanganannya :

\section{Pre-Operatif}

a. Nyeri

Nyeri didapatkan sebelum operasi pada pasien ini NRS 3, sehinnga di ruangan diberikan analgetik paracetamol flash.

b. Rehidrasi

Pada pasien luka bakar derajat IIA, maka sesuai rumus baxter penggantian cairan pada pasien ini adalah :

Rumus Baxter : 1-3 tahun

$$
\begin{aligned}
= & \mathrm{BB} \times 75 \mathrm{CC} \\
= & 15 \times 75 \mathrm{cc} \\
= & 1.125 \mathrm{cc} / \text { hari } \\
& 1 / 2 \text { Jumlah cairan diberikan dalam } 8 \\
& \text { jam pertama }=560 \mathrm{cc} .
\end{aligned}
$$

\section{Cairan yang diberikan pada Anak :}

$$
\begin{aligned}
\text { RL }: \text { DEXTRAN } & =17: 3 \\
& =480: 80
\end{aligned}
$$


Infus yang digunakan adalah RL dan Dextrose $5 \%$ dengan perbandingan diatas. Tetesan infus yang digunakan tetes makro sebagai berikut :

$=$ (Kebutuhan cairan $\mathrm{X}$ faktor tetes makro)/waktu (jam)/waktu (menit).

$=(560 \times 20) / 8 / 60$

$=1400 / 60$

$=24 /$ menit

Yang artinya dalam satu menit, jumlah tetesan infus sebanyak 28 tetes, 1/2 Diberikan 16 jam berikutnya $=560 \mathrm{cc}$ dengan rincian sebagai berikut :

Infus yang digunakan adalah RL dan Dextrose $5 \%$ dengan perbandingan diatas.

Tetesan infus yang digunakan tetes makro sebagai berikut:

$=$ (Kebutuhan cairan $\mathrm{X}$ faktor tetes makro)/waktu (jam)/waktu (menit)

$=(560 \times 20) / 16 / 60$

$=700 / 60$

$=12 /$ menit

Yang artinya dalam satu menit, jumlah tetesan infus sebanyak 12 tetes.

\section{Intra Operatif}

a. Nyeri

Analgetik yang diberikan pada pasien ini saat operasi adalah paracetamol dengan dosis $10 \mathrm{mg} / \mathrm{kgBB}$.

$$
\begin{aligned}
\text { Dosis } & =\text { BB X } 10 \\
& =15 \times 10 \\
& =150 \mathrm{mg}
\end{aligned}
$$

b. Terapi cairan
Terapi cairan pasien saat operasi sesuai dengan rumus maintenance dan stress operasi disesuaikan dengan rumus Baxter diatas.

\section{Post Operatif}

a. Nyeri

Nyeri pada pasien post op ini diberikan obat analgetik paracetamol disesuaikan dengan berap badan pasien dosis 3x $150 \mathrm{mg}$.

b. Terapi Cairan Terapi cairan dilanjutkan dengan rumus Baxter.

\section{KESIMPULAN}

Anestesi umum (General anesthesia) disebut juga tindakan meniadakan nyeri secara sentral disertai hilangnya kesadaran dan bersifat reversible berdasarkan trias anesthesia yang ingin diperoleh yaitu hipnotik, analgesia, dan relaksasi otot. Prosedur anastesi umum dan monitoring pasien tidak hanya dilakukan pada saat operasi tetapi juga mencakap persiapan pra anastesia (kunjungan dan premedikasi) dan pasca anastesia. Pemilihan teknik intubasi pada anastesi umum didasarkan pada jenis operasi yang akan dilakukan, usia, jenis kelamin, status fisik pasien, keterampilan pelaksana anastesi, ketersediaan alat, serta permintaan pasien.

Pada kasus di atas, pasien laki-laki, usia 3 tahun dengan berat badan $15 \mathrm{~kg}$ 
datang dengan keluhan nyeri pada kedua telapak tangan karena luka bakar. Tindakan yang dilakukan pada pasien yaitu debridement. Pemilihan tindakan anestesi pada pasien ini adalah General Anestesi Face Mask (Sungkup Muka) dan hasil pemeriksaan didapatkan status fisik ASA I. Dasar pemilihan tindakan anastesi pada pasien tersebut adalah lokasi, durasi, manipulasi dari pembedahan, dan posisi.

\section{DAFTAR PUSTAKA}

Cushieri A, Grace PA, Darzi A, Borley N, Rowley DI. Clinical surgery. Blackwell publishing. 2008.

Dorland, Newman W., 2012, Kamus Saku Kedokteran Dorland Edisi 28, EGC: Jakarta.

Goodman and Gilman's. 1985. The pharmacological bases of therapeutics. $7^{\text {th }}$ edition. New York : Mac Millian Publishing Co. Inc.

Latief S, A., Suryadi K, A., Dachlan M, R. 2009. Petunjuk Praktis Anestesiologi Edisi Kedua. Penerbit Bagian Anestesiologi dan Terapi Intensif FKUI: Jakarta.

Moenadjat, Y., 2005 Petunjuk Praktise Penatalaksanaan Luka Bakar. Asosiasi Luka Bakar Indonesia Diterbitkan oleh Komite Medik Asosiasi Luka Bakar Indonesia.

Moore KL. 2002. Anatomi klinis dasar. Dalam. Jakarta: EGC.

Morgan GE, Mikhail MS, Murray MJ. 2006. Patient monitors. In : Lange Medical Books Clinical Anesthesiology. 4th eds. New York.
Rosari, Bella. 2016. General Anestesi dengan Face Mask.

Ting, H. Paul. Intravenous Anesthetic. Available at : http://anesthesiologyinfo.com/articles /01072002.php. Accesed : 20 Juli 2019.

Syamsuhidayat R \& Wim de Jong. 2012. Buku Ajar Ilmu Bedah Edisi Revisi. 